\title{
SCOPES AND OPPORTUNITIES OF BUFFALO FARMING IN BANGLADESH: A REVIEW
}

\author{
M. A. Hamid ${ }^{*}$, M. N. A. Siddiky ${ }^{2}$, M. A. Rahman ${ }^{3}$ and K. M. Hossain ${ }^{4}$ \\ ${ }^{1}$ School of Agriculture and Rural Development, Bangladesh Open University, Gazipur-1705, \\ Bangladesh \\ ${ }^{2}$ SAARC Agriculture Centre, BARC Complex, Farmgate, Dhaka-1215, Bangladesh \\ ${ }^{3}$ Department of Genetics and Animal Breeding, Faculty of Veterinary and Animal Science, \\ Sylhet Agricultural University, Sylhet-3100, Bangladesh \\ ${ }^{4}$ Biotechnology and Genetic Engineering Discipline, Khulna University, Khulna- 9208, \\ Bangladesh
}

\begin{abstract}
The present study attempts to examine the scenario of buffalo production in Bangladesh. The buffalo plays a very important role in the South Asian region which constitutes $77.5 \%$ of world buffalo population. This region has a great biodiversity in buffalo germplasm, including the world famous source promising buffaloes Murrah and Nili-Ravi - renowned for high milk production potential. It is estimated that about $96.05 \%$ of Asia and $93.19 \%$ of world buffalo milk are produced in South Asian countries. Besides, buffalo milk in South Asian countries is around $54.95 \%$ of the total milk production. The India and Pakistan share $67.99 \%$ and $23.96 \%$, of world buffalo milk production respectively. About $71.4 \%$ of world buffalo meat is produced in South Asian countries. Although buffalo is an integral part of livestock production system in South Asian countries, it has never been addressed in Bangladesh and always neglected despite their important role in the national economy. In Bangladesh, the total buffalo population are 1.464 million heads that are managed in household subsistence farming as well as extensive free range (Bathan) farming in saline coastal region that are used as a draught animal and partially for milk and meat production. The contribution of buffalo in total milk and meat production in Bangladesh is only $2.0 \%$ and $0.94 \%$, respectively. This review has tried to unearth the present scenario of buffalo production in Bangladesh, describing the benefits and values of buffalo milk and meat, advantages of buffalo husbandry over cattle, constraints in buffalo production and recommendations for buffalo development in Bangladesh.
\end{abstract}

Keywords: Bangladesh, buffalo, milk, meat, farming

\footnotetext{
*Corresponding author email: hamidethu@yahoo.com
}

Received: 19.07.2016 


\section{INTRODUCTION}

Buffalo is a multipurpose domestic animal that helps the livelihood of people by providing high quality milk and meat, dung as fuel and organic fertilizer; mechanical or draft power and hides and skins as raw material for industry (Irshad et al., 2011). Buffaloes are extensively used for agricultural production system (ploughing, laddering, transportation of goods, threshing and crushing etc.) in Bangladesh. Indigenous domestic buffaloes of Bangladesh belongs to the Bubalus bubalis with most of the population are riverine type with exception of some swamp type found in eastern part of the country. Its crosses (Faruque et al., 1990) with Murrah, Nili-Ravi, Surti and Jaffrabadi are scantly available surrounding Indian border of Bangladesh due to border migration from India (Huque and Borghese, 2012). Bangladesh imported a small number of Nili-Ravi from Pakistan during 1960s without any comprehensive improvement program. Department of Livestock Service (DLS) again imported 100 Nili-Ravi pregnant heifers and cows in first lactation from Pakistan during 1990 and reared in newly established buffalo breeding and development farm at Bagerhat district, in south-west part of Bangladesh. But the breed was not maintained properly and mixed up with local buffalo through male distribution program of the DLS.

In Bangladesh, buffalo has never been addressed and remained neglected species despite their important role in the national economy. The global buffalo population is 194.29 million and buffalo in Asia dominate the world population, representing $92.52 \%$ (179.75 million) of the total buffalo population (FAO, 2012; Chakravarty, 2013). Within the Asian region, about $79.74 \%$ of buffaloes are in South Asian countries and the rest $20.26 \%$ in other countries. India and Pakistan are the two buffalo rich countries in the world that contributes $58.11 \%$ and $16.83 \%$ of world buffalo population, respectively. In Bangladesh, the total buffalo population is about 1.464 million (DLS, 2015) of which coastal regions possess about 40\% (Faruque et al., 1990). The per capita consumption of livestock products is much higher in developed countries and substantial growths have also occurred in developing countries of Asia except Bangladesh (FAO, 2009). In Bangladesh, recent year's rapid growth of urbanization, poverty reduction, increase in middle class, and their increased income have changed their food preferences. These recent developments have major impacts on demand for animal derived products such as milk, meat, butter, cheese, ice-cream, baby foods, locally made traditional sweets which are merely dependent on milk.

Though the buffalo is an important part of livestock in Bangladesh, there is no documented research studies so far that investigated the scopes and opportunities of buffalo production in Bangladesh. The purpose of this study is to examine the status of Bangladesh related to buffalo production. In order to develop buffalo production in Bangladesh, it would be worthy to know details about buffalo population, buffalo breeds, and their production and reproduction performances, contribution of buffalo 
to milk and meat production. Therefore, the present study was undertaken to identify the status of buffalo production in Bangladesh and to find out the constraints in buffalo production and provide recommendations of buffalo development in Bangladesh.

\section{A brief profile of Bangladesh}

Bangladesh is the largest delta in the world and is situated between $88^{\circ} 10$ and $92^{\circ} 41$ East longitudes and between $20^{\circ} 34$ and $26^{\circ} 38$ North longitudes. The total area is about $147,570 \mathrm{~km}^{2}$. The topography is variable and can be divided into (i) high, the land above normal flood level; (ii) medium, the land normally flooded up to about 90 $\mathrm{cm}$; (iii) low, the land normally flooded up to $300 \mathrm{~cm}$; (iv) very low, the land normally flooded deeper than $300 \mathrm{~cm}$ during the flood season and (v) the hilly land. According to variations in agro-ecology, soil physiography and climatic factors the total area of the country is divided into 30 agro-ecological zones.

Bangladesh has tropical and moderate climate with the summer, monsoon, autumn, late autumn, winter and spring seasons. Annual minimum temperature varies from $8^{\circ} \mathrm{C}$ to $13.4^{\circ} \mathrm{C}$ and maximum temperature varies from $25.5^{\circ} \mathrm{C}$ to $36.8^{\circ} \mathrm{C}$ Annual rainfall is over $2000 \mathrm{~mm}$ with seasonal and regional variations from $5500 \mathrm{~mm}$ in the Northeast to $1500 \mathrm{~mm}$ in the West. The highest rainfall in the monsoon season (June to September) varies from $750 \mathrm{~mm}$ per month in the Northeast to about $500 \mathrm{~mm}$ in the West. The humidity is the highest (95\%) in July and the lowest (36\%) in December.

During the monsoon (June to August) heavy rains results in inundation of about $30 \%$ of the plain land. On the other hand, during the dry season (February to mid May) the country use to experience a high sunshine and low humidity and it compels to pump up a huge amount of underground water and during the dry period most of the farmers except those of the river basin area face a serious feed shortage that limits livestock production. Thus, variations in crop productions due to climate and topography greatly affect the livestock production system in the country.

The total human population of Bangladesh is about 160 million of which rural and urban population is about $76.57 \%$ and $23.43 \%$, respectively. The average population growth rate is about $1.1 \%$ and average density of population is $1033 / \mathrm{km}^{2}$. The adult literacy rate (15 years and over) is 55.9\%. The per capita GDP is 1677 (US\$) and the growth rate of real GDP is $5.8 \%$. The contribution of livestock in agricultural GDP is about $14.21 \%$ (DLS, 2016).

\section{Population of buffalo and other dairy animals in Bangladesh compare to South Asian countries}

In Bangladesh, cattle, goat and buffalo are considered as dairy animals. Out of total milk production, about $90 \%$ share is from cattle, $8 \%$ from goat and the remaining $2 \%$ from buffalo (DLS, 2015). According to the data of DLS (2015) there are about 23.636 million cattle, 25.602 million goats and 1.464 million buffaloes in 
the country (Table 1). Among the total cattle population, about 6 million are dairy cattle of which about $85-90 \%$ are indigenous and $10-15 \%$ are crossbred (Islam and Rashid, 2012). Indigenous cattle consisted of (a) Non-descript Deshi, (b) Red Chittagong cattle, (c) Pabna cattle, (d) North Bengal Gray and (e) Munshiganj White cows. On the other hand, crossbred cattle are the results of crossing between local with different exotic breeds like Holstein, Friesian, Jersey, Sindhi and Sahiwal, at different level. Black Bengal, the only dairy goat breed comprises $90 \%$ of the total population. Buffalo in Bangladesh is mainly indigenous in origin and most of them are riverine type with exception of some swamp type in eastern part and have low productivity. There are also some cross breed with Murrah, Nili-Ravi, Surti and Jaffrabadi surrounding of Indian border (Faruque et al., 1990; Huque and Borghese, 2012).

Table 1. Population of dairy animals in Bangladesh compare to South Asian countries

(Figure in millions)

\begin{tabular}{l|c|c|c|c|c|c|c|c}
\hline $\begin{array}{c}\text { Species } \\
\text { /Countries }\end{array}$ & Afghanistan & Bangladesh & India & Pakistan & Nepal & $\begin{array}{c}\text { Sri } \\
\text { Lanka }\end{array}$ & Bhutan & Maldives \\
\hline Cattle & 5.244 & 23.636 & 199.075 & 36.908 & 7.226 & 1.35 & 0.366 & NA \\
Goat & 7.311 & 25.602 & 140.537 & 63.146 & 9.513 & - & 0.039 & NA \\
Buffalo & - & 1.464 & 106.0 & 33.7 & 5.0 & 0.475 & 0.001 & NA \\
\hline
\end{tabular}

Source: (1) India, Report of Department of Animal Husbandry, Dairying \& Fisheries, Ministry of Agriculture 2013; (2) Bangladesh, DLS, 2015; (3) Sri Lanka, Department of Census and Statistics, Sri Lanka 2012; (4) Bhutan, Bhutan RNR Statistics 2012; (5) FAO, 2012; 6) NA = data not available and in SAARC countries.

Asian buffaloes dominate the world population, representing $92.52 \%$ of the worldwide population of 194.29 million (FAO, 2012). Within the Asian region, about $79.74 \%$ of buffaloes are in South Asian countries and the rest $20.26 \%$ in other countries (Chakravarty, 2013). The buffalo populations in the world, in Asia and in South Asian countries are presented in table 2. During the last decades, world buffalo population has increased by 20.0 million heads and $89.41 \%$ of that increase occurred in Asia, in fact, that population growth has been largely contributed by India and Pakistan (FAO, 2012). It is evident from the table that India is the highest buffalo populated country in the world followed by Pakistan. 
Table 2. Buffalo populations in South Asian countries in comparison with Asia and all over the world

\begin{tabular}{lcc}
\hline Region/Country & Total population (million) & Share in world population (\%) \\
\hline World & 194.29 & $100 \%$ \\
Asia & 179.75 & $92.52 \%$ \\
Rest of world & 14.54 & $7.48 \%$ \\
India & 112.91 & $58.11 \%$ \\
Pakistan & 32.70 & $16.83 \%$ \\
Nepal & 4.99 & $2.57 \%$ \\
Bangladesh & 1.464 & $0.753 \%$ \\
Sri Lanka & 0.405 & $0.208 \%$ \\
Bhutan & 0.000851 & - \\
\hline
\end{tabular}

Source: FAO, 2012; Chakravarty, 2013

\section{Milk production potentiality of buffalo in different countries}

The production potentiality of buffaloes in different countries is presented in table 3. According to production potentiality, it is observed that Pakistan and India has the highest milk producing buffaloes than others. Pakistani Nili-Ravi buffalo is the best performing buffalo in the world for milk production and average milk yield for all lactations has been reported $1820 \mathrm{~kg}$ in 305 days lactation (Nivsarker et al., 2000). Munish Kumar (2004) reported average milk production of Murrah buffaloes are $8.45 \pm 0.32 \mathrm{~kg}$ per day. India is home to diverse biodiversity of buffalo germplasm, including the world famous Murrah buffaloes- renowned for higher milk production potential as well as wider use of improver breed for local buffaloes.

Table 3. Average buffalo milk production in different countries

\begin{tabular}{|l|l|}
\hline Country & $\begin{array}{l}\text { Average milk yield } \\
\text { (kg/animal/lactation) }\end{array}$ \\
\hline Pakistan & 1909 \\
\hline India & 1407 \\
\hline Vietnam & 1000 \\
\hline Turkey & 969 \\
\hline Nepal & 842 \\
\hline Sri Lanka & 648 \\
\hline China & 505 \\
\hline Bangladesh & 407 \\
\hline Asia & 1389 \\
\hline
\end{tabular}

Table 4. Buffalo milk production in the world as well as in South Asian countries

\begin{tabular}{lccc}
\hline Region/Country & $\begin{array}{c}\text { Total production } \\
(\mathrm{MT})\end{array}$ & $\begin{array}{c}\text { Share in world } \\
\text { production }(\%)\end{array}$ \\
\hline World & 95.815 & 100 \\
Asia & 92.962 & 97.02 \\
Rest of world & 6.525 & 2.98 \\
SAARC countries & 89.29 & 93.19 \\
India & 65.14 & 67.99 \\
Pakistan & 22.955 & 23.96 \\
Nepal & 1.109 & 1.157 \\
Bangladesh & 0.037 & 0.039 \\
Sri Lanka & 0.046 & 0.048 \\
Bhutan & 0.000084 & - \\
\hline
\end{tabular}

Source: Chakravarty, 2013 
The average milk production of Murrah buffaloes has been reported $1618 \mathrm{~kg}$ in 305 days lactation and peak yield of herds recorded 7.93 $\pm 0.16 \mathrm{~kg}$ (Kumar, 2000).

\section{Contribution of buffalo in Bangladesh in comparison with South Asian Countries}

The contribution of buffalo to total milk production in Bangladesh remained more or less stagnant due to absence of any milk improvement program. Whereas, in India, the buffalo forms the backbone of India's dairy industry which share $67.99 \%$ of world's buffalo milk production (Chakravarty, 2013). India is also the world's topmost milk producer as well as largest exporter of dairy and dairy products globally. Pakistan is the second largest milk producing country in South Asian region. The total milk production scenarios in South Asian counties are presented in figure 1. The buffalo meat production systems in Bangladesh are traditional and inefficient. Most of the meat comes from end of the career, or emergency slaughter animals.

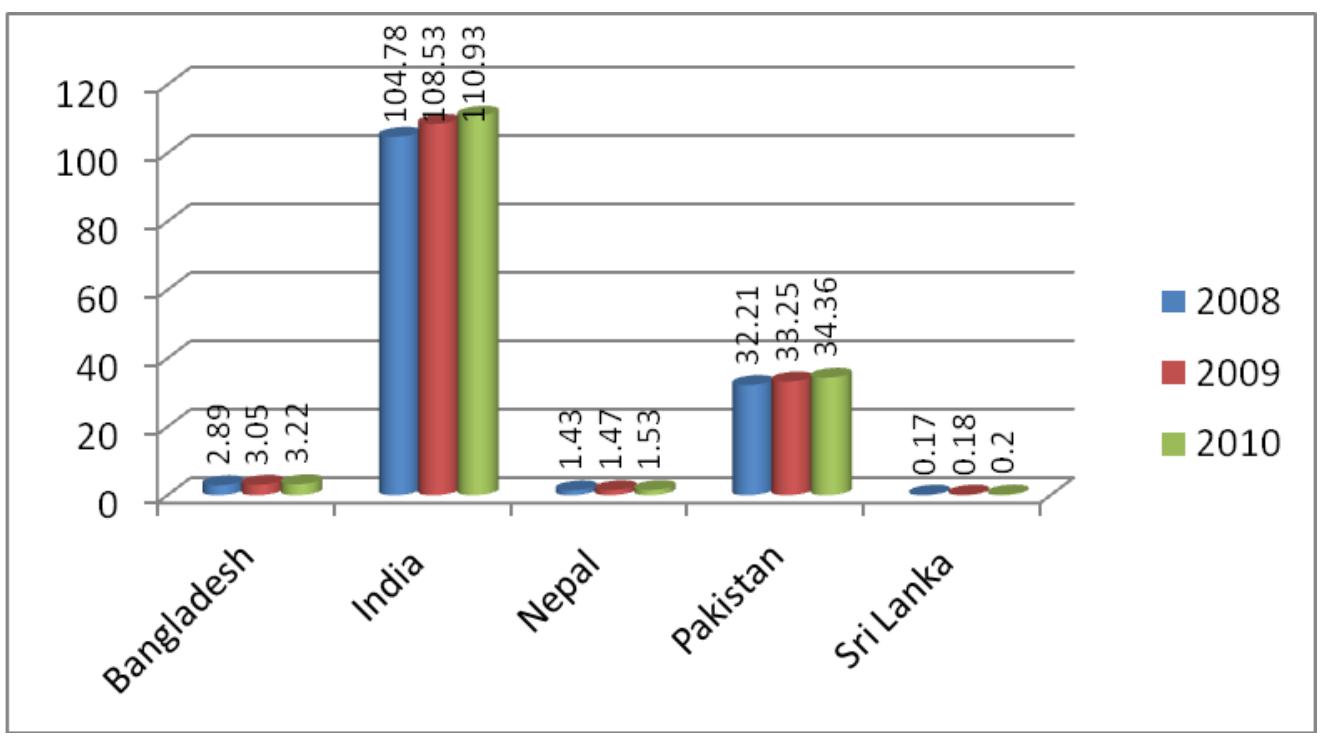

Figure 1. Total milk production scenarios in South Asian Countries (MT)

The buffalo milk production in South Asian countries represents 96.05\% Asian and $93.19 \%$ of world's total buffalo milk production (Chakravarty, 2013). India and Pakistan contributed $67.99 \%$ and $23.96 \%$ of total buffalo milk production in the world. The buffalo milk production in the world in comparison with Asian countries and South Asian countries are presented in table 4.

The Asian countries represent $91.89 \%$ of world's buffalo meat and with volume of 3.08 metric tons in 2008 (FAO, 2010). About 78.5\% of Asian buffalo meat was produced in South and South West Asia with the greater bulk contributed by India and followed by Pakistan (Table 5). India is the world's fourth meat producing 
country and largest buffalo meat exporting country globally. Improvement in buffalo meat yield is contributed by the increasing usage of male calves which were not fully utilized. Earlier in India, farmers were not paying enough attention to rescue the young animals from high mortality before reaching 6 months of age. In recent years, however, the rising export of Indian buffalo meat have given enough incentives for small herd farmers to rear these animals and put additional weight prior to slaughter, thereby sustaining the growth in the meat harvest from the Indian buffalo sector.

Table 5. Buffalo Meat Production (tons) in the World as well as in South Asia during $1998-2008$

\begin{tabular}{l|l|l|c}
\hline Year & World & South Asia & Share in world production $(\%)$ \\
\hline 1998 & $2,881,073$ & $1,959,142$ & 68.0 \\
2004 & $3,112,609$ & $2,169,537$ & 69.7 \\
2005 & $3,171,721$ & $2,202,409$ & 69.4 \\
2006 & $3,249,474$ & $2,333,324$ & 71.8 \\
2007 & $3,327,645$ & $2,357,359$ & 70.8 \\
2008 & $3,358,946$ & $2,398,922$ & 71.4 \\
\hline
\end{tabular}

Source: FAOSTAT, 2010

\section{Requirements and availability of milk and meat in Bangladesh}

Consumption of milk and milk products in the country is carried out in different ways: directly from the producers, from the vendors and from the commercial milk processors and manufacturers. An adult person requires at least $250 \mathrm{ml}$ milk every day, but the availability is only about $125.59 \mathrm{ml} /$ day/head (DLS, 2016). This figure indicates that we are in shortage of milk production. Total milk production of the country is 7.27 MMT/year but the requirement is about 14.69 MMT/year (DLS, 2016). From this figure it is observed that the deficiency is about $49.77 \%$ (Table 6). If we compare the milk and meat consumption pattern of our country with South Asian countries, then it is apparent that our position is at the bottom of all South Asian countries in terms of milk and meat consumption. 
Table 6. Requirement, availability and deficit of meat and milk in Bangladesh

\begin{tabular}{c|c|c|c|c|c}
\hline Products & $\begin{array}{c}\text { Need per } \\
\text { capita }\end{array}$ & $\begin{array}{c}\text { Availability per } \\
\text { capita }\end{array}$ & Production/year & Demand/year & Deficiency \\
\hline Milk & $250 \mathrm{ml} / \mathrm{h} / \mathrm{d}$ & $\begin{array}{c}125.59 \mathrm{ml} / \mathrm{h} / \mathrm{d} \\
(50.23 \%)\end{array}$ & $7.27 \mathrm{MT}$ & $14.69 \mathrm{MT}$ & $\begin{array}{c}124.41 . \mathrm{ml} / \mathrm{h} / \mathrm{d} \\
7.41 \mathrm{MT}(49.77 \%)\end{array}$ \\
& & & & $13.79 \mathrm{gm} / \mathrm{h} / \mathrm{d}$ \\
Meat & $120 \mathrm{gm} / \mathrm{h} / \mathrm{d}$ & $\begin{array}{c}106.21 .64 \mathrm{gm} / \mathrm{h} / \mathrm{d} \\
(88.5 \%)\end{array}$ & $6.15 \mathrm{MT}$ & $7.05 \mathrm{MT}$ & $0.9 \mathrm{MT}(11.5 \%)$ \\
\hline
\end{tabular}

Source: DLS, 2016

The huge gap between supply and demand is largely met by import of milk powder and cream from abroad. For this reason the country looses huge amount of foreign currency every year which is about USD 93.4 million (Bangladesh Bank, 2012-13). Moreover, this powder milk which is importing from abroad is not totally safe for human consumption because in the past, melamine (hazardous chemical dangerous for human health) was detected in the powdered milk from China. During 2008, powdered milk price in the international market was USD 5000-5500 per ton and it affected the price of liquid milk in the local market which increased and remained high (BDT 30-38 per liter) until March 2009 (Chowdhury, 2009). The increasing trend of liquid milk price resulted gradual flourishing of many small scale commercial dairy farms in the country. In addition, the high income elasticity of demand for milk mentioned earlier is good potential for growth in the dairy sectors. Attainment of high growth rate in the sector would immense the opportunity to millions of smallholder producers and others entrepreneurs in milk processing and marketing business and may create an opportunity for poverty reduction through employment and income generation. Dairy generates more regular cash income, and dairy production, processing and marketing generate more employment per unit value added compare to crops (Omore et al., 2002).

\section{Benefits and values of buffalo milk and meat}

Buffalo milk contains less water, more total solids, fat and protein, slightly more lactose than cow's milk. It seems thicker than cow's milk because it generally contains more than $16 \%$ total solids compared with $12-14 \%$ for cow's milk. In addition, it's fat content (6-8\%) is usually $50-60 \%$ higher (or more) than cow's milk. Buffalo milk has considerably higher energy value than cow's milk because of its higher butter fat content. However, buffalo milk has significantly lower cholesterol content $\left(0.65 \mathrm{mg} \mathrm{g}^{-1}\right)$ as compared to the corresponding value of $3.14 \mathrm{mg} \mathrm{g}^{-1}$ for cow milk (FAOSTAT, 2012). Fat globules of buffalo milk are larger in size, white in colour and have higher anti oxidant tocopherol peroxidase (2-3 times more than cow milk). Buffalo milk has about 11.42 percent higher protein than cow milk and is also superior to cow milk in terms of important minerals, namely calcium, iron and 
phosphorus that are higher by $92 \%, 37.7 \%$ and $118 \%$ respectively than those present in cow milk. Buffalo metabolizes all the carotene into vitamin A, which is passed on to milk as such. The nutritional composition of milk of different species has shown in table 7 .

Table 7. Nutritional composition of milk of different species (per 100 grams)

\begin{tabular}{lcccccc}
\hline Constituents & Unit & Cow & Goat & Sheep & Buffalo \\
\hline Water & $\mathrm{gm}$ & 87.8 & 88.9 & 83.0 & 81.1 \\
Protein & $\mathrm{gm}$ & 3.2 & 3.1 & 5.4 & 4.5 \\
Fat & $\mathrm{gm}$ & 3.9 & 3.5 & 6.0 & 8.0 \\
Carbohydrate & $\mathrm{gm}$ & 4.8 & 4.4 & 5.1 & 4.9 \\
Energy & $\mathrm{K}-\mathrm{cal}$ & 66 & 60 & 95 & 110 \\
Sugars (Lactose) & $\mathrm{gm}$ & 4.8 & 4.4 & 5.1 & 4.9 \\
Saturated Fatty Acids & $\mathrm{gm}$ & 2.4 & 2.3 & 3.8 & 4.2 \\
Cholesterol & $\mathrm{mg}$ & 14 & 10 & 11 & 8 \\
Calcium & $\mathrm{IU}$ & 120 & 100 & 170 & 195 \\
Phosphorus & $\mathrm{mg}$ & 90 & 120 & - & 130 \\
Iron & $\mathrm{mg}$ & 0.2 & 0.3 & - & 0.2 \\
\hline
\end{tabular}

Source: FAOSTAT, 2012.

Buffalo milk is commercially more viable than cow milk for the manufacture of fat-based and SNF-based milk products, such as butter, butter oil (clarified butter or ghee), soft and hard cheeses, condensed or evaporated milks, ice cream, yoghurt and butter milk because of its lower water content and higher fat content. Most significantly, the lower cholesterol value should make it more popular in the health conscious market. By the virtue of greater opacity of casein micelles coupled with higher levels of colloidal proteins, calcium and phosphorus, buffalo milk is more densely white and has superior whitening properties as compared to cow milk. UHTprocessed buffalo milk and cream are intrinsically whiter and more viscous than their cow milk counterparts, because of conversion of greater levels of calcium and phosphorus into the colloidal form. Buffalo milk is, therefore, more aptly suitable for the production of tea and coffee whiteners than cow milk. Higher innate levels of proteins and fat render buffalo milk a more economical alternative to cow milk for the production of casein, caseinates, whey protein concentrates and a wide range of the fat-rich dairy products. Buffalo milk more suitable for production of yogurt and cheese especially soft cheese than cow milk. To produce $1 \mathrm{~kg}$ of cheese, a cheese maker requires $8 \mathrm{~kg}$ of cow's milk but only $5 \mathrm{~kg}$ of buffalo milk. To produce $1 \mathrm{~kg}$ of butter, a butter maker requires $14 \mathrm{~kg}$ of cow's milk but only $10 \mathrm{~kg}$ of buffalo milk. 
Buffalo meat is very tender and tasty and healthy red meat substitute for beef. It is faster to cook, easier to digest, has no allergenic effect and $E$ Coli problems. It has beneficial impact on cardiovascular risk profile. According to the report of US Department of Agriculture, it showed that water buffalo meat has superior quality as compared to cattle. The analysis shows that the buffaloes meat has $40 \%$ less cholesterol, 12 times less fat, 55\% less calories, $11 \%$ more proteins and $10 \%$ more minerals. It is good source of Beta carotene and Vit- $\mathrm{B}_{12}$ (Kandeepan and Biswas, 2007). The nutritional composition of meat of different species is shown in table 8 . Buffalo meat is dark red in colour, firm in consistency with white fat colour. More pigmentation or less intra muscular fat (1-2\% marbling compared with 3-4\% in beef) content causes darker appearance of buffalo meat. The dark meat possesses good binding properties and is preferred in product manufacture (Kondaiah, 2002).

Table 8. Nutritional composition of meat of different species (per 100 grams)

\begin{tabular}{ccc|c|c}
\hline Constituents & Unit & Chicken & Beef & $\begin{array}{c}\text { Buffen or } \\
\text { carabeef }\end{array}$ \\
\hline Protein & gm & 16.7 & 24.07 & 26.83 \\
Fat & gm & 7.41 & 9.2 & 2.42 \\
Calories & K-cal & 190 & 211 & 143 \\
Cholesterol & mg & 89 & 86 & 82 \\
Iron & $\mathrm{mg}$ & 1.21 & 2.99 & 3.42 \\
Vit-B12 & $\mathrm{mg}$ & 0.33 & 2.64 & 2.86 \\
\hline
\end{tabular}

Source: USDA Agriculture Handbook

\section{Benefits of buffalo carcass than beef in dressing percentage and composition}

Young male buffaloes are usually slaughtered at 12-24 months when they weigh 250-300 $\mathrm{kg}$. The dressing percentage varies with age and type of animal slaughtered. Mediterranean-type (Brazil) of buffalo yields a dressing percentage of $55.51 \%$. Average dressing percentage on moderate diet is about 55.4-59.0. Buffalo veal yields about 61-64\% (Bhat and Lakshmanan, 1998). The carcass composition varies with dressing percentage of buffalo carcasses. A buffalo having dressing percentage of $43-44$ is composed of $65-70 \%$ meat, $5-10 \%$ fat and $20-24 \%$ bone. A buffalo broiler having a dressing percentage of 51.4 constitutes $66.8 \%$ meat, $9.7 \%$ fat and $23.5 \%$ bone (Bhat and Lakshmanan, 1998). Buffalo carcass has rounder ribs, a higher proportion of muscle and a lower proportion of bone and fat than beef.

\section{Buffalo meat in our country - the facts}

Buffalo meat is not popular in Bangladesh, but its low cholesterol level and higher quality than cattle may attract the consumers, if quality tender meat is 
available like cattle. Hasnath (1985) reported that the average live weight of buffalo at slaughter age was about $320 \mathrm{~kg}$ where the dressing percentage was $44 \%$ only. It was reported that the average live weight of adult buffalo was $427 \mathrm{~kg}$ (BBC, 2012). Almost all buffaloes in Bangladesh are slaughtered at older age after completing their whole life in works and are usually very emaciated. The meat fiber is very sticky and hard to chew. However, a large number of buffaloes are slaughtered every day in the city market and sold in disguise of beef with lower price than beef. In general, the quality of meat is one of the main reasons for less acceptance by the consumers. The buffalo meat price is about taka 370/kg against cattle meat price taka 420/kg which is always lower in between taka 50 to 75 per kilogram (One US\$= Taka 80) as tender aged quality buffalo meat is not at all available in common market. These taboos of low quality buffalo meat can be changed by introducing tender aged buffalo meat marketing through buffalo improvement program in the country.

\section{Advantages of buffalo husbandry over cattle}

\section{Work/Animal traction}

The water buffalo is an important beast of burden in Asian farming and also it is called Asian Tractor. It is widely used to plough, level land, plant crops, puddle rice fields, cultivate field crops, pump water, haul carts, sleds and shallow-draft boats. It is also used to carry people, thresh grain, press sugar cane, haul logs, and more. Buffalo have an advantage over other draught animals in wet or muddy areas, with their large hooves. Their legs can withstand wet conditions better than cattle. However they are not as fast as cattle, horses or mules. This puts them at a disadvantage in dryer areas. Therefore, the additional income every year through the sale of surplus milk is vital to their well-being and economic security.

\section{Utilization of feeds: conversion of meat and milk}

The most important and desirable quality of the water buffalo is its extraordinary capacity of utilization less digestible feeds (straw, sugar cane wastes etc.) than cattle. So it requires less concentrate feeds than cattle. This mean that it can produce excellent quality food meat and milk using only crop residues, pasture, and mineral salts, without the addition of supplement concentrates.

\section{Prevalence of diseases}

Buffalo is highly adaptable and healthy animal that can resist infectious and contagious diseases. However, they must receive the same vaccines, hygienic care and dedicated attention as do cattle. The females, because they produce nutritive milk, transfer their calves more resistance to dangerous diseases. There is no report of mad cow disease in buffalo from any part of the world.

\section{Enrich soil fertility}

Buffalo enrich soil structure and fertility while tracking paddy field. Each year, an adult buffalo produce 4-6 tons of wet manure plus additional urine as bio-fertilizer. 
This reduces the requirement of chemical fertilizers as well as provides soil humus that chemicals cannot provide.

\section{More resistance to climatic hazard}

Buffalo can survive against tidal wave better than any other livestock species. This is evidence from the cycles that occurs frequently in the coastal area of Bangladesh.

\section{No housing requirement}

Buffalo does not require expensive house as like cattle. It can even live in open air throughout the year. For $99 \%$ of buffaloes in Bangladesh, there is no house at all. This is true in many parts of world.

\section{Inherent qualities as meat producer}

Buffaloes have a unique ability to utilize coarse feeds, straws and crop residues converting them into protein rich lean meat. Hence buffaloes fit well in poor countries having poor feed resources. Buffalo properly managed and fed as a meat producing animal and slaughtered at 16 to 20 months of age yields a highly satisfactory top quality meat at a much lower cost than the cattle (Ranjan and Pathak, 1979). Since buffaloes have been used as draught animals for centuries, they have evolved with exceptional muscular development. Until recently, little thought was given to use them exclusively for meat production. Buffaloes are lean animals. The sub-cutaneous fat layer of the carcass is usually thinner than that on comparably fed cattle. Fat is low even under feed lot conditions.

More lean and less fat compared to cattle, has created a demand for it among health conscious consumers (Kondaiah, 2002). Buffaloes have higher degree of resistance and tolerance than cattle against many diseases. They are reasonably productive up to 15 years of age and at 18 years and even more it may produce calves. Buffaloes have excellent body weight gain compared to other species. The nutrient requirements of buffalo steer include $0.24 \mathrm{~kg}$ DCP, $1.8 \mathrm{~kg}$ TDN, $6.6 \mathrm{MCal} \mathrm{ME}, 14 \mathrm{~g}$ $\mathrm{Ca}$, and $11 \mathrm{~g} \mathrm{P}$. On Adlibitum and high concentrate (75:25) based rations the growth rate is $610 \mathrm{~g} \mathrm{day}^{-1}$ with feed efficiency of 7:1. On all roughage rations (Green berseem/ berseem hay) the growth rate is $370 \mathrm{~g}$ day $^{-1}$ with feed efficiency of 10:1 (Ranjan and Pathak, 1979).

\section{Constraints of buffalo development in Bangladesh}

Low productivity of the indigenous buffaloes due to low genetic potential, low input services for the buffalo keepers, lack of public awareness about buffalo husbandry, less interest in buffalo farming, scarcity of feeds and fodder, seasonality of reproduction, lack of breeding bulls and infrastructure, poor attention in buffalo research and development, no progeny testing programs, shortage of technical manpower for buffalo husbandry, higher calf mortality, scarcity of proven breeding bulls, slow adoption of artificial insemination and impact of global warming. 


\section{Recommendations of buffalo development in Bangladesh}

$\checkmark$ Developing/strengthening the breeding infrastructure

$\checkmark \quad$ In intensive production system, continuous up gradation of native buffaloes in the plain land with imported semen of Murrah, Nili-Ravi or Mediterranean breed having good pedigree record for production.

$\checkmark \quad$ In semi-intensive production system, crossbreeding of native buffaloes with Murrah or Nili Ravi and fixed 50\% exotic bloods followed by inter se mating.

$\checkmark \quad$ In low input production system, crossbreeding of native buffaloes with Murrah or Nili Ravi and fixed 50\% exotic bloods followed by inter se mating.

$\checkmark \quad$ Conservation of the swamp buffaloes at greater Sylhet and Chittagong districts through establishment of farms in respective regions.

$\checkmark \quad$ Breeding, feeding and disease preventive measures should be adjusted accordingly. Reproductive biotechnology should not be ignored.

$\checkmark \quad$ Public awareness for buffalo production by different media; Radio, TV, Newspaper etc. should be created.

$\checkmark \quad$ Quality fodder seed production farms should be established. Increase the land for fodder production should be ensured.

$\checkmark \quad$ Development of manpower by technical training should be ascertained.

$\checkmark \quad$ National research and international collaboration should be strengthened.

$\checkmark \quad$ Buffalo milk and meat market and infrastructure should be developed.

$\checkmark \quad$ Private investment is to be explored and encouraged to invest in buffalo development infrastructure including marketing of milk and meat products in the country.

\section{CONCLUSION}

This paper aims to discuss the present situation and future prospects of buffalo production in Bangladesh. Buffalo could be a major source of milk and meat to reduce the milk and meat demand gap in Bangladesh. The analysis provided an overview of Bangladesh with the importance of the industry and the current problems facing the industry. The discussion shows that there is a vast demand for milk and meat and a great employment opportunity in Bangladesh. Buffalo improvement program through scientific crossbreeding with quality breed with improved feed and management system and technical knowledge along with milk value chain in different farming systems will increase the production of buffalo in Bangladesh.

\section{REFERENCES}

Bangladesh Bank. 2013. Annual Report, Bangladesh Bank, Government of the People's Republic of Bangladesh, Dhaka, Bangladesh 
BBC (Bangladesh Buffalo Centre). 2012. Lal Teer Livestock Report(personal communication)

Bhat, P. N. and Lakshmanan, V. 1998. The Buffalo meat Industry in India. An over view. In: Buffalo prod. health. $1^{\text {st }}$ publication. ICAR pp. 185-214

Chakravarty, A. K. 2013. Strategies for genetic improvement of buffaloes through production of quality male germplasm in SAARC countries. Seminar paper presentation in "High Yielding Dairy Buffalo Breed Development in SAARC Countries, SAARC Agriculture Centre, BARC Complex, Farmgate, Dhaka-1215

Chowdhury, S. A. 2009. Economics of fodder production in Bangladesh. Paper presented in national workshop on- Fodder Production and Artificial Insemination held on 21 May, 2009. Polli Karma Sahayak Foundation (PKSF), Sher-e-Bangla Nagar, Dhaka, Bangladesh

DLS. 2014. Annual Report on Livestock, Division of Livestock Statistics, Ministry of Fisheries and Livestock, Farmgate, Dhaka, Bangladesh

DLS. 2015. Annual Report on Livestock, Division of Livestock Statistics, Ministry of Fisheries and Livestock, Farmgate, Dhaka, Bangladesh

DLS. 2016. Annual Report on Livestock, Division of Livestock Statistics, Ministry of Fisheries and Livestock, Farmgate, Dhaka, Bangladesh

FAO. 2009. Food and Agricultural Organization. The State of Food and Agriculture

FAO. 2010. Food and Agricultural Organization. Production Yearbook 2008

FAO. 2011. Food and Agricu1tural Organization, Division of Animal Production and Health

FAO. 2012. Food and Agricultural Organization. The State of Food and Agriculture

FAOSTAT. 2010. FAO statistical database. FAO Statistics Division

FAOSTAT. 2012. FAO statistical database. Available at: http://faostat.fao.org/. Accessed 21 September 2012

Faruque, M. O., Hasnath, M. A. and Siddique, N. U. 1990. Present status of buffaloes and their productivity. Asia-Australian Journal Animal Science, 3: 287-292

Hasnath, M. A. 1985. Breeding, feeding and management of water buffalo in Bangladesh. In proceedings of $3^{\text {rd }}$ AAAP Animal Science Congress, Tokyo, Japan. 1: 70-79

Huque, Q. M. E. and Borghese, A. 2012. Production potentiality and perspective of buffalo in Bangladesh. In: Proc. 15th AAAP Animal Science Congress (Abstract), 26-30 November, 2012, Thailand.pp.244

Irshad, A., Tariq, M. M., Bajwa, M. A., Abbas, F., Isani, G. B., Soomro, G. H., Waheed, A. and Khan, K. U. 2011. A study on performance analysis of Holstein-Friesian cattle herd under semi intensive management at Pishin Dairy Farm Balochistan. Journal of Institute Science and Technology, Igdir, Turkey, 1: 53-57

Islam, M. N. 2015. Safe Milk for Healthy Nation. $9^{\text {th }}$ Biennial Conference and International Seminar, Dhaka, Bangladesh. Pp. 37-54

Islam, M. N. and Rashid, M. H. 2012. Dairying in Bangladesh: Present Scenario and Strategies for Future Development. Paper presented in the Seminar and Reception: Animal Husbandry Education and Profession in Bangladesh- A journey of 50 years organized by Bangladesh Animal Husbandry Association, Dhaka, Bangladesh. Pp. 6672 
Kareemulla and Meena. 2004. In: Buffalo production under different climatic regions.

Kandeepan, G. and Biswas, S. 2007. Effect of domestic refrigeration on keeping quality of buffalo meat. Journal of Food Technology, 5(1): 29-35

Kondaiah, N. 2002. Meat and by products. In: Handbook of Animal Husbandry. 3rd revised edition. pp. 950-975. New Delhi, India: DIPA, ICAR

Munish Kumar. 2004. Studies on management practices of Nili Ravi buffalo in Ferozepur district of Punajb. M. V. Sc. Thesis submitted to National Dairy Research Institute, Deemed University, Karnal, Haryana, India

Nivsarker, A. E., Vij, P. K. and Tantia, M. S. 2000. Animal Genetic Resources of India: Cattle and Buffalo. Directorate of Information and Publications of Agriculture, ICAR, New Delhi, India

Omore, A., Mulindo, J. C., Islam, S. M. F., Nurah, G., Khan, M. I., Staal, S. and Dugdill, B. T. 2002. Employment generation through small scale dairy marketing and processing: Experiences from Kenya, Bangladesh and Ghana. FAO, Rome, Italy

Ranjan, S. K. and Pathak, N. N. 1979. Management and feeding of buffaloes. Pp. 217-227. New Delhi, India: Vikas Publishing House

Siddiky, M. N. A. 2013. Perspectives of high yielding dairy buffalo breed development in SAARC countries. Seminar paper presentation in "High Yielding Dairy Buffalo Breed Development in SAARC Countries", SAARC Agriculture Centre, BARC Complex, Farmgate, Dhaka-1215

USDA Agriculture Handbook. 1958. Agriculture Handbook No. 116, United States Department of Agriculture, Washington. D. C 